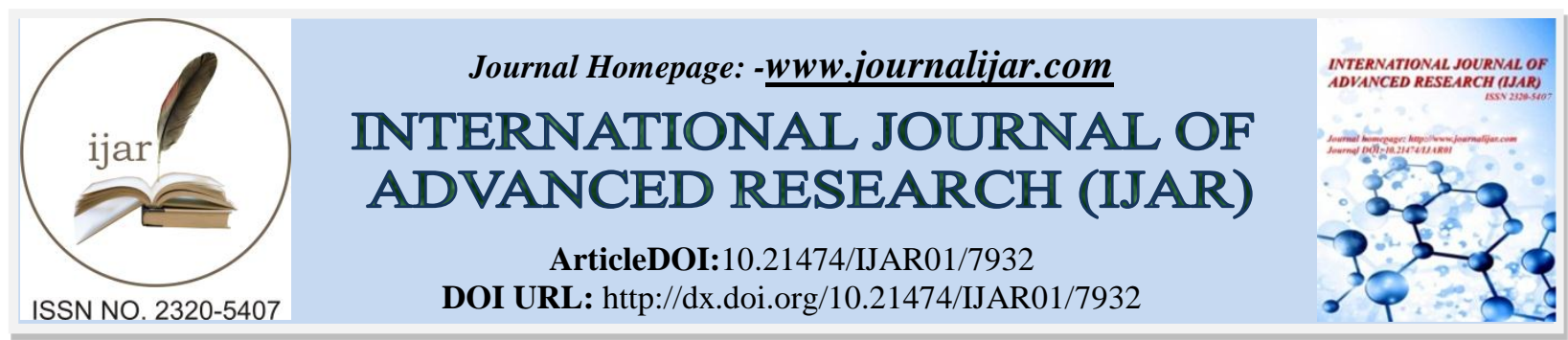

RESEARCH ARTICLE

\title{
GENERAL ELECTIONS 2018 IN BRAZIL: IS DEMOCRACY RESTORED?
}

\section{Dr. Murillo de Oliveira Dias ${ }^{1}$ and Andre Teles, LLM $^{2}$.}

1. DBA coordinator,Fundação Getulio Vargas, Brazil.

2. LLM Practitioner, Fundação Getulio Vargas, Brazil.

\section{Manuscript Info}

Manuscript History

Received: 14 August 2018

Final Accepted: 16 September 2018

Published: October 2018

Keywords:-

vote, general election, democracy.

\begin{abstract}
On October 28, 2018, the far-right candidate, Jair Messias Bolsonaro was officially declared the winner of the race to Brazilian Presidency 2018. In one of the most controversial and fiercely disputed elections, over 147 million voters have chosen their representatives for the next four-eight years term (eight years for senators). The winner, Bolsonaro, survived after being stabbed in the middle of his campaign, on September 6. Haddad, looser, represented the former president Lula da Silva, convicted and sentenced to 12-years imprisonment for passive corruption and money laundering, who was coordinating the campaign from jail. Evidence suggested a divided country. Nevertheless, the Congress emerged renewed, and the far-left defeated in the majority of states. Moreover, political differences were pacifically solved through the vote. Therefore, in this article, facts and figures were investigated on general election 2018. From paper-based to electronic suffrage, we analyzed its outcomes since 1989. It took only two hours to sum up all votes, in contrast with past elections, where the counting could take several days. Current facts and figures are analyzed in this single case study. Finally, recommendations for future research complete the present work.
\end{abstract}

Copy Right, IJAR, 2018,. All rights reserved.

\section{Introduction:-}

This research investigated the single, descriptive case study, on Brazilian general election 2018, aiming at the presidential elections study (Yin, 1988).

General election 2018 was one of the most controversial of the Brazilian newly free period, after the military dictatorship regime (1964-1985). The country found divided between far-left and far-right candidates. Jair Bolsonaro, 63 years old, born in São Paulo state, southeastern Brazil was declared president on October 28, 2018, at GMT 10:21 PM (7:21 PM GMT -3, Brasilia time), only approximately two hours after the counting votes start. Brazil has adopted electronic vote system since 1998 president election. The system itself is controversial, due to the possibility of electronic fraud, discussed in this work.

Nevertheless, 147,306,294 voters elected state governors, federal and state members of Congress, senators and one vice-president. Voting in Brazil is mandatory for citizens between 18 and 70 years of age. Facultative for citizens from 16 to 17 and up to 70 years old (TSE, 2018). It is possible to justify absence in the poll, for traveling voters. It 
is also possible to vote in transit. In total, 500,727 Brazilian residing abroad are eligible to vote only for president in General Elections 2018.

The general elections in Brazil were held in a two-round system, for state governors, vice-president, and president. Federal and state members of Congress, along with senators were disputed in one round only. The voting system followed the majority criterion (50 percent plus one vote).

The first round was disputed on October 7. The second one, on October 28, 2018, both dates on Sundays (TSE, 2018). This work presents the results of the general election of 2018, focused on the presidential race (Yin, 1988).

The vote is defined as "1: to express one's views in response to a poll; 2: to express an opinion; 3: to choose, endorse, decide the disposition of, defeat, or authorize by vote" (Merriam-Webster dictionary, 2018). The word vote comes from Latin votumand means "a vow, wish, promise to a god, solemn pledge, dedication" (Etymology, 2018). According to Dias \& Teles, "a vote is a formal indication of choice. It can be written, a raised hand, or an electronic one, for instance. It is the manifestation of someone's wish" (2018, p.1.).

Brazilian Federal Constitution 1988 establishes on Article 14: "the vote is direct and secret, one vote per citizen in equal value" (Brasil, 1988).

This article is limited to investigate Brazilian general election 2018, the unit of analysis in this single, descriptive case study (Yin, 1988). Municipal, state, senator races are not part of this work, although mentioned in facts. The general elections investigated here are the president ones.

The next section presents facts and figures regarding the general elections 2018. The background on political issues that have driven this controversial poll are presented and discussed. The role of the electronic vote system is also analyzed and discussed. Future research recommendations complete the present work.

General election 2018: background

Following Dias \& Teles "in 1964, a coup d'état led by the armed forces against president João Goulart's administration, has plunged Brazil into a military regime (1964-1985), where direct elections were forbidden. Elections in this period were indirect" (2018, p.4). The Brazilian military regime lasted 21 years (Carvalho, 2000). The first election was indirect and took place in 1988 (Nicolau, 2002). Nevertheless, the first direct elections of the newly democratic regime were held on November 15 th, 1989. Table 1 depicts the total voters in Brazil, from 1989 to 2018, as follows:

Table 1:-Total Voters for presidential elections (1989-2018)

\begin{tabular}{ccc}
\hline Year & Total voters & President Elected \\
\hline \hline 2018 & 147.302 .357 & Jair Messias Bolsonaro \\
2014 & 142.825 .280 & Dilma Roussef \\
2010 & 135.804 .433 & Dilma Roussef \\
2006 & 125.913 .134 & Lula da Silva \\
2002 & 115.254 .113 & Lula da Silva \\
1998 & 106.101 .067 & Fernando Henrique Cardoso \\
1994 & 94.732 .410 & Fernando Henrique Cardoso \\
1989 & 82.074 .718 & Fernando Collor de Mello \\
\hline
\end{tabular}

Source:-Tribunal Superior Eleitoral, TSE (2018); Dias \& Teles (2018). 
Next, Figure 1:- depicts the evolution of the total of voter in Brazil, as follows:

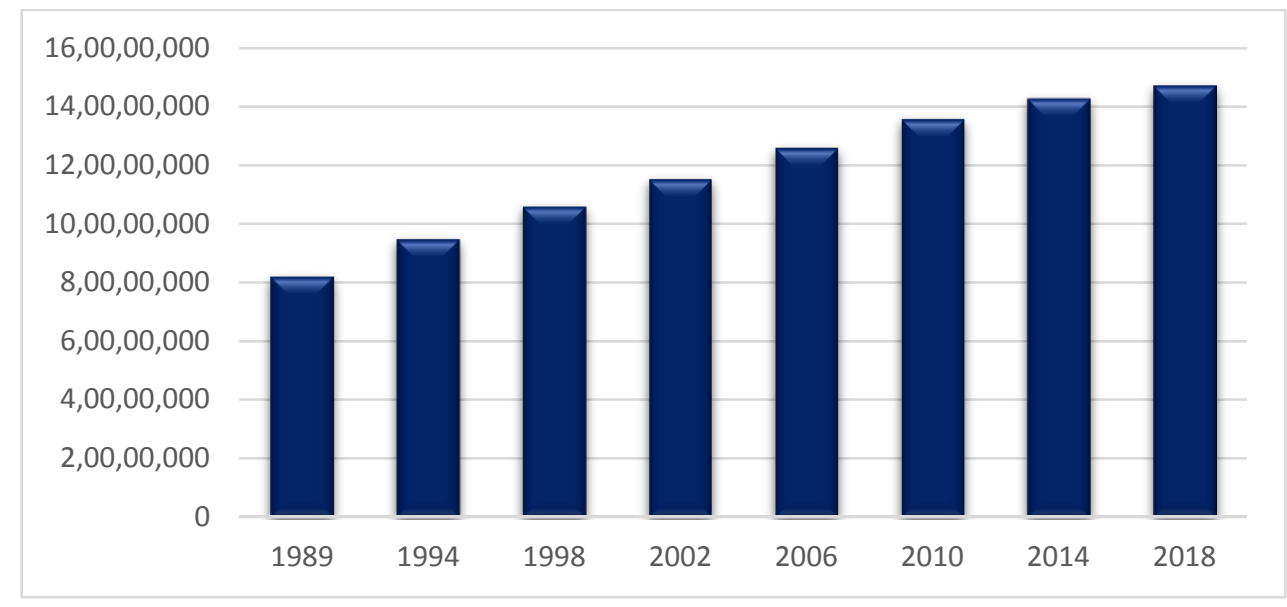

Figure 1:- Total Brazilian voters evolution (1989-2018). Source: TSE, 2018.

In the sequence, on Figure 2:-, the distribution of Brazilian voters by region is shown, as follows:

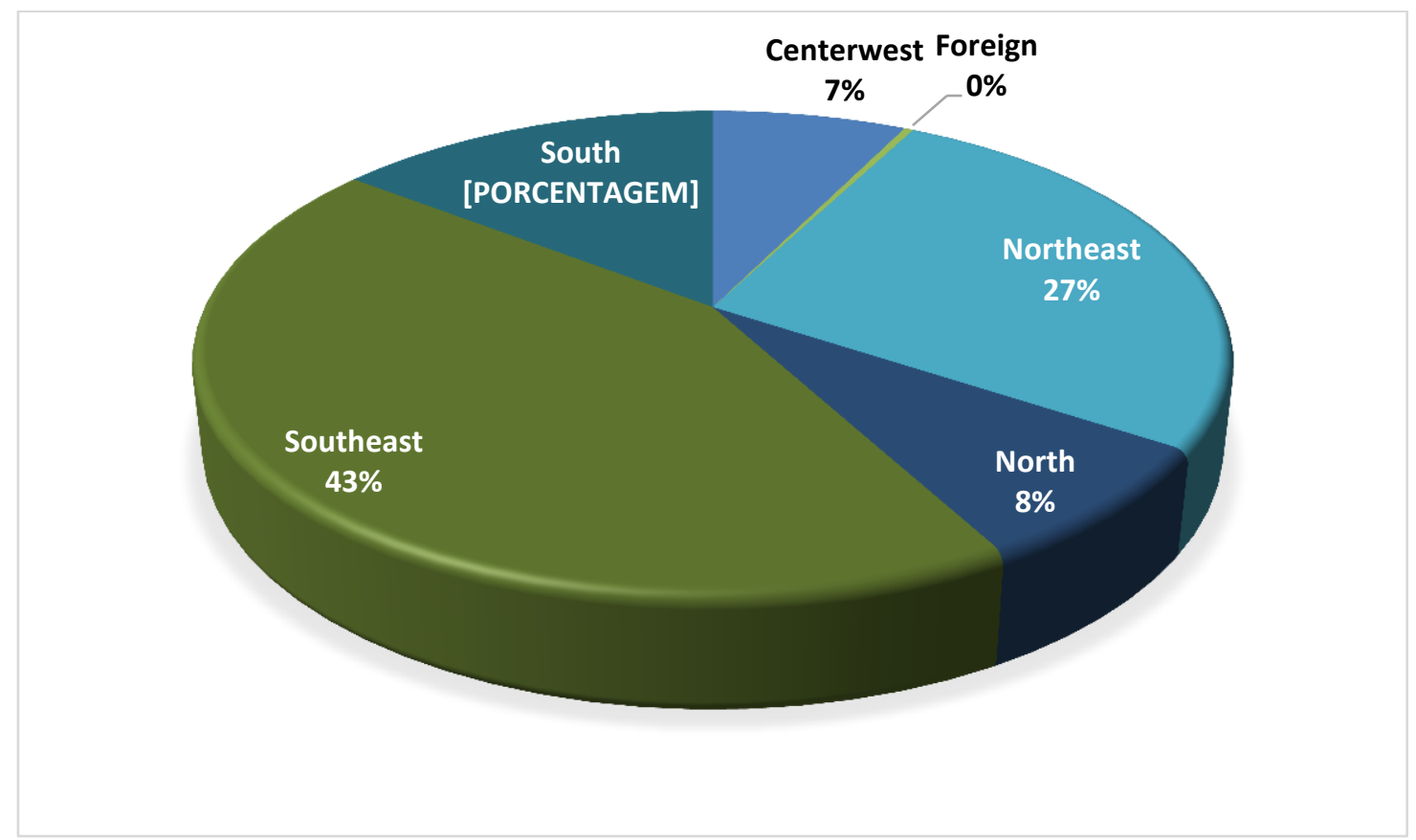

Figure 2:-voters' regionaldistribution. Source: TSE, 2018

Table 2:-depicts the total voters distributed in 27 states plus the Federal district and living abroad voters (ZZ voters). The largest Brazilian electoral college is in the state of São Paulo, Southeastern region, exactly 33, 040,411 voters, representing $22.43 \%$ of the total (TSE,2018). 
Table 2:-Brazilian voters per state.

\begin{tabular}{|c|c|c|}
\hline State & \# voters & $\%$ \\
\hline $\mathrm{AC}$ & 547.680 & 0,372 \\
\hline $\mathrm{AL}$ & 2.187 .967 & 1,485 \\
\hline $\mathrm{AM}$ & 2.428 .098 & 1,648 \\
\hline AP & 512.110 & 0,348 \\
\hline BA & 10.393 .170 & 7,056 \\
\hline $\mathrm{CE}$ & 6.344 .483 & 4,307 \\
\hline DF & 2.084 .356 & 1,415 \\
\hline ES & 2.754 .728 & 1,87 \\
\hline GO & 4.454 .497 & 3,024 \\
\hline MA & 4.537.237 & 3,08 \\
\hline MG & 15.700 .966 & 10,659 \\
\hline MS & 1.877 .982 & 1,275 \\
\hline MT & 2.330 .281 & 1,582 \\
\hline PA & 5.499 .283 & 3,733 \\
\hline PB & 2.867 .649 & 1,947 \\
\hline PE & 6.570 .072 & 4,46 \\
\hline PI & 2.370 .894 & 1,61 \\
\hline PR & 7.971 .087 & 5,411 \\
\hline RJ & 12.406 .396 & 8,422 \\
\hline $\mathrm{RN}$ & 2.373 .619 & 1,611 \\
\hline RO & 1.175 .733 & 0,798 \\
\hline $\mathrm{RR}$ & 331.490 & 0,225 \\
\hline $\mathrm{RS}$ & 8.354 .732 & 5,672 \\
\hline $\mathrm{SC}$ & 5.070 .212 & 3,442 \\
\hline SE & 1.577 .058 & 1,071 \\
\hline SP & 33.040 .411 & 22,43 \\
\hline TO & 1.039 .439 & 0,706 \\
\hline $\mathrm{ZZ}$ & 500.727 & 0,34 \\
\hline 27 & 147.302.357 & $100 \%$ \\
\hline
\end{tabular}

Source:- TSE, July 2018

The next section presents the Methods constant in the present research. 


\section{Methods and research limitations:-}

The present work, combined interpretive, qualitative study, developed under multiple methods, such as descriptive single case study (Yin, 1988), along with archival research, especially on the Electoral Superior Court (Tribunal Superior Eleitoral - TSE). The unit of analysis is the Brazilian general elections 2018 (Yin, 1988). The case is also supported by the Agency theory (Eisenhardt, 1989), since there are principals (Brazilian citizens) and their representative agents (president, vice president, senators, members of congress, and state governors).

Secondary data were investigated through archival research based on data available on the Tribunal Superior Eleitoral (TSE, Superior Electoral Court, our translation), and text analysis.The aforementioned Court, is the highest instance of the Brazilian Electoral Justice. In turn, TSE regulates state courts - Regional Electoral Courts (Tribunal Regional Eleitoral, TRE), responsible each of the 26 states, plus the Federal District (DF), according to Federal Constitution 1998, Article 118 (Brasil, 1988).

This article is limited to Law no. 9.504, from September 30, 1997, issuing on Article 1, " that the general elections should take place on the first October's Sunday of the electoral year" (Brasil, 1997). Also rules: (a) parties' colligations (Art.6); (b) conventions for choosing candidates (Art.7); (c) candidates' applications (Art.10); (d) campaign funding (Art.16, and 17); (e) Campaign accountability (Art. 28); (f) electoral propaganda (Art. 36); (g) the electronic system of voting and the voting totalization (Art.59); (h) election oversight (Art. 65); and (i) election crimes (Art.72), the most important ones (Dias \& Teles, 2018).

This article is also limited by Complimentary Law $\mathrm{N}^{\circ} 135$, from June 4, 2010, as known as Lei da Ficha Limpa (Clean record Law), losing their electoral rights for eight years (Brasil, 2010, Article 1, item "d").

The next section presents the results of this investigation, starting with the electronic voting results.

\section{General Election 2018: electronic voting:-}

In 1989, the presidential election's paper ballots took nine days to be fully counted and checked. In 2002, vote count took 12 hours to be accomplished (TSE, 2018). In 2018, only two hours and 21 minutes were necessary to point the new president, roughly 108 times faster than in 1989. The e-voting (electronic voting) system evidenced to be very useful in vote counting, in comparison to the paper ballot system (TSE, 2018).

Brazil adopted the electronic voting system entirely in the general election 2002. Paraguay and Ecuador loan the machines for national polls. Countries like Switzerland, Norway, Australia, Ireland, Belgium, among others, also adopted electronic vote in local and general elections, depending on each case (TSE, 2018).

The electronic vote is not an entirely safe system, because it is exclusively dependent on software and operating system which can be in turn manipulated or hacked, or present malfunction. If a ballot machine malfunctions, Law 9.504/ 1997, establishes on Art. 83-89 that paper ballots shall substitute the electronic vote "in sections were the electronic vote unavailable or present malfunction at the moment of voting, for instance, among others" (Brasil, 1997, art 83-89). In general elections 2018, second round, exactly 4,658 electronic devices were substituted for paper ballots due to malfunction, 860 only in São Paulo state - the more significant number of substitutions (TSE, 2018).

The security levels were improved through the adoption ofbiometrics-based voting machine. It was formally adopted on September 16, 2008. To the general election 2018, 73,688,211 voters were biometrically identified, representing 50.03 percent of voters (TSE, 2018).

Electoral e-voting fraud on the machines is a crime, punishable by imprisonment are from five to ten years, according to Law 9.504/ 1997, Art. 72 (Brasil, 1997, items I, II and III).

Finally, the total number of ballot boxes replaced in this second round, 4,333 machines, represents 0.95 percent of the total of 454,493 ballot boxes installed for the second round of the general elections 2018 (TSE, 2018).

\section{Clean Record Law:-}

In general election 2018, 2,016 candidates were prohibited from disputing positions due to the Complimentary Law $\mathrm{N}^{\mathrm{o}}$ 135, from June 4, 2010, as known as Lei da Ficha Limpa (Clean Record Law, our translation), for those who "had a final decision or rendered by a collegiate body, in the process of verifying abuse of economic or political 
power, for the election in which they compete or have been graduates, as well as for those that take place in the next eight (8) years (Brasil, 2010, Article 1, item "d"). Losing their electoral rights for eight years. In 2018, 2,016 candidates (6.96 percent) had applications contested by the Electoral Justice (TSE, 2018).

Therefore, only 26,941 out of 28,957 candidates, from 35 political parties, ran for the general elections 2018 . Among the absent were the candidacy for president from labor party, (PT), the convicted former president Lula da Silva, on September 1, 2018 (TSE,2018).

Almost three-quarters of the current members of congress tried to re-elect in 2018 but were defeated. The general elections 2018 represented a significant defeat to Labor Party - PT (TSE, 2018).

The general elections 2018 involved six political office positions: (a) president; (b) vice-president; (c) state governor; (d) senator; (e) federal congressman, and (f) state or district congressman District members of Congress to dispute the Federal District (DF) positions.The general elections 2018 involved six political office positions: (a) president; (b) vice-president; (c) state governor; (d) senator; (e) federal congressman, and (f) state or district congressman ${ }^{1}$. The candidates elected will serve a term beginning on January 1, 2019, for four years' office term, only senators for senators who have eight years' term in office. The positions per candidates are depicted in Table 3 , as follows:

Table 3:-General elections 2018: positions per candidates

\begin{tabular}{ccc}
\hline Positions & Candidates & $\%$ \\
\hline \hline President & 14 & $0,05 \%$ \\
Vice-president & 14 & $0,05 \%$ \\
Governor & 200 & $0,69 \%$ \\
Vice-governor & 205 & $0,71 \%$ \\
Senator & 357 & $1,23 \%$ \\
Congressmen Federal & 8.553 & $29,54 \%$ \\
Congressmen State & 17.875 & $61,73 \%$ \\
Congressmen District & 974 & $3,36 \%$ \\
Senator $1^{\circ}$ Suplente & 377 & $1,30 \%$ \\
Senator $2^{\circ}$ Suplente & 388 & $1,34 \%$ \\
\hline TOTAL & $\mathbf{2 8 . 9 5 7}$ & $\mathbf{1 0 0 \%}$ \\
\hline
\end{tabular}

Source:- TSE, 2018

\section{Controversies:-}

The most intriguing case, however, involved the former president, Luis Inacio Lula da Silva. After losing four consecutive president races, he won in 2002 and was re-elected for a second term in 2010, later supporting Dilma Rousseff candidacy for president, who substituted him from 2010 to 2016. Former president Dilma has suffered impeachment in 2016, and the vice-president, Michel Temer completed the presidential mandate until December 31, 2018. (TSE, 2018).

\footnotetext{
${ }^{1}$ District members of congress to dispute the Federal District (DF) positions.
} 
Lula has been judged, convicted and sentenced to 12 years imprisonment, for money laundering, passive corruption by Judge Sergio Moro, from TRF 4, Parana State Court of Justice (TSE, 2018).

Lula is pointed to be the head of the worst corruption scandal, and one of the worst governments in the entire Brazilian history. He also started running his campaign from prison, accusing Michel Temer administration of Coup d'état in the United Nations, and took his case to the Brazilian Supreme Court, in vain. His last attempt to run the general elections was finally silenced by the Tribunal Superior Eleitoral, who decided by six votes against one, on August 31, 2018, on a special session, to definitively reject Lula's candidacy. On September 1, the Labor party (PT) announced Fernando Haddad as Lulas's substitute and pointed the far-left Manuela D'Avila as his candidate for the vice-president position (TSE, 2018).

If the convicted Lula by chance won the elections, he could become the first president to rule Brazil from jail. Haddad promised to set free Lula, if elected president, violating all Brazilian Justice decisions against the one convicted and sentenced candidate. Foreign media such as the British the Guardian stated that "the fate of Lula da Silva is the very fate of Brazilian democracy" (the Guardian 2018, page 1), defending Lula's political rights, disregarding the Brazilian Justice verdicts and sentences, even the higher Brazilian Court decisions, without presenting any evidence. The result of the general elections 2018 provided substantial evidence that the British journal and other opposition were wrong since the majority of the votes for the presidency were against Lula, or his puppet, Fernando Haddad, who lost the election 2018. According to Dias and Teles (2018),

The aggressor, Adélio Bispo de Oliveira, was arrested and declared, that he stabbed Bolsonaro obeying a divine order, an "act of God". The aggressor was framed in the National Security Law, n' 7.170, from December 14th, 1983. He justified the action against the far-right politician due to his controversial commentaries, who has outraged Adelio about some racist and homophobic Bolsonaro's comments (p.12).

Bolsonaro had a $12 \mathrm{~cm}$ intestinal perforation, pierced by a $30 \mathrm{~cm}$ kitchen knife blade, and suffered many surgical interventions. He was prohibited by doctors of taking part in campaign rallies, until his full health recovery.

\section{General Elections 2018: Results:-}

Jair Messias Bolsonaro, from PSL Party - Liberal Social Party (Partido Social Liberal) won by a difference of ten million votes (TSE, 2018). The result of the second round of the president election is depicted in Figure 3, as follows:

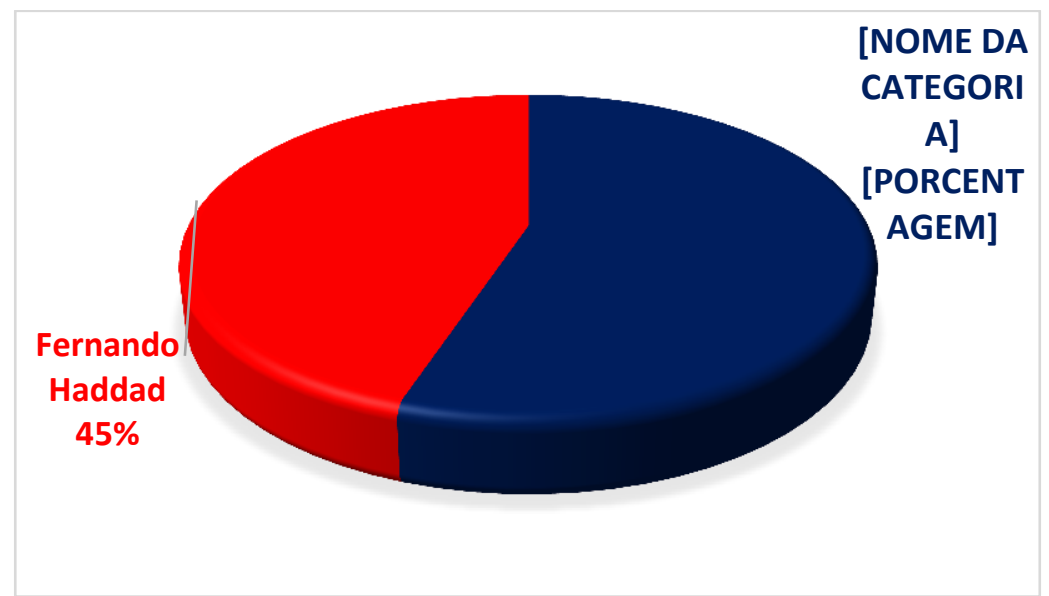

Figure 3 :- Results of president election 2018. Source: TSE, 2018

The winner, President Jair Bolsonaro, received 57,797,847 votes (55.1 percent of the valid votes), against 47,040,906 votes for the second position, Fernando Haddad, (44.9 percent).In the first round, Jair Bolsonaro (PSL) had 49,277,010 votes (46.03 percent), against 31,342,051 (29.28 percent) of the votes to Fernando Haddad (PT). Jair Bolsonaro is the $38^{\text {th }}$ Brazilian President elected and shall take position on January $1^{\text {st }}, 2019$ at Brasilia.

The two candidates were eligible to dispute the second round of the race election for president, on October 28,2018 (TSE, 2018). In Table 4, the overall votes results in the two rounds system, is depicted, as follows: 
Table 4:-Results of the General Elections, 2018. Source: TSE, 2018.

\begin{tabular}{lllll}
\hline Votes 2018 & \multicolumn{2}{l}{ Round 1 (October 7) } & \multicolumn{2}{l}{ Round 2 (October 28) } \\
\hline \hline White votes & 107050673 & $91,21 \%$ & 104838753 & $90,43 \%$ \\
Null votes & 7206205936 & $2,65 \%$ & 2486593 & $2,14 \%$ \\
Pending votes & 746 & $6,14 \%$ & 8608105 & $7,43 \%$ \\
Total & 117364654 & $79,67 \%$ & 115933451 & $78,70 \%$ \\
Absent & 29941171 & $20,33 \%$ & 31371704 & $21,30 \%$ \\
Non taken & 470 & $0,01 \%$ & 1139 & $0,01 \%$ \\
\hline \hline Total voters & 147306294 & $100 \%$ & 147306294 & $100 \%$ \\
\hline
\end{tabular}

In Figure 4:-the official logo for general elections 2018 is depicted, as follows:

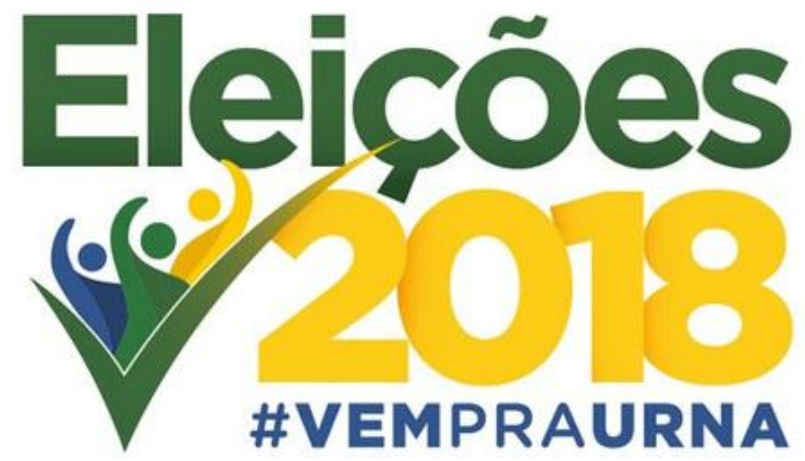

Figure 3 :-Official logo - Election 2018. Source: TSE, 2018

The general election 2018 ended with the winning of Jair Bolsonaro in 16 states, as depicted in Figure 5, as follows: 


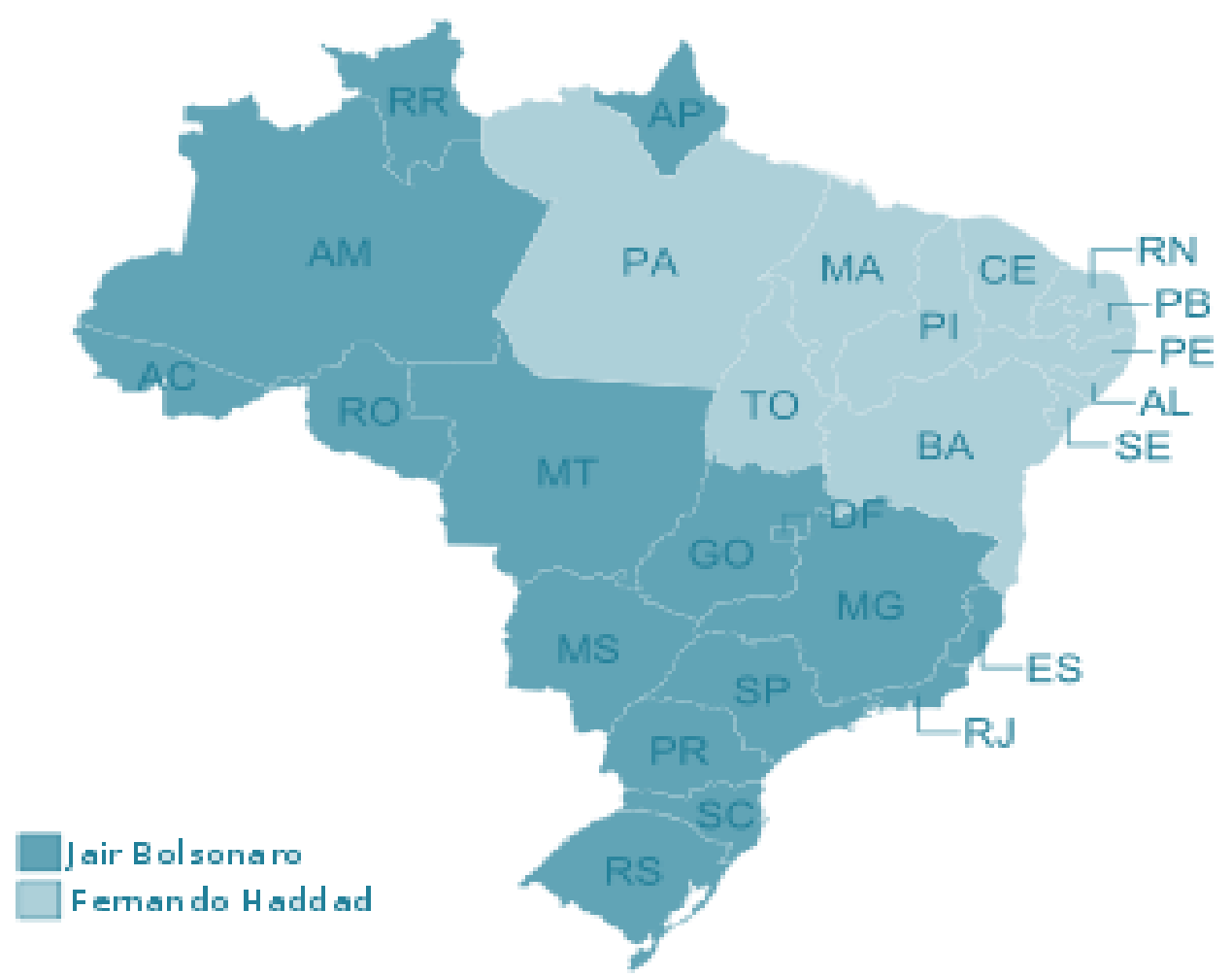

Figure 4:-Result of president elections 2018 per state and Federal District. Source: TSE, 2018.

\section{Case analysis: a new way of running elections:-}

On June 2018, TSE announced the total amount of the Federal Campaign Fund to be distributed among parties: BRL 1.7 billion (approximately USD 460 million), through Resolution TSE 23.568/2018. Bolsonaro's party, Partido Social Liberal (PSL), and the Patriot Party (PATRIOTA), refused to withdraw the proportional amount addressed to the party's campaign (TSE, 2018).

The following features marked the general election 2018 in Brazil: (a) strong social network participation: (b) fake news spread all over networks, mainly in Whatsapp, Twiter, Facebook, and Youtube (TSE, 2018).

Bolsonaro adopted the less expensive campaign, conquering millions of followers in the social networks, who in turn helped to spread word to mouth. He led the polls about voting intentions since the beginning of the president race.

Bolsonaro's campaign has been marked by controversial declarations against minorities, such as gays, and lesbians. He upholds the following government agenda items, not restricted to: (a) family values, (b) population rearmament, against gender educational policy for children, (d) social security reform, (e) privatization, (f) support to entrepreneurs and simplification of the Brazilian business managerial system, (g) eradication of corruption in Brazil, eradication of violence in Brazil, among others.

As a member of the Social Liberal Party (PSL), he was federal deputy for seven terms between 1991 and 2018, being elected through different parties throughout his career. He has three sons, all elected politicians in 2018: Carlos Bolsonaro (Rio de Janeiro, for PSC), Flávio Bolsonaro (state congressman of Rio de Janeiro for PSL and commander of the legend in the state), and Eduardo Bolsonaro (Federal congressman in São Paulo also by the PSL).

Bolsonaro entered the reserve in 1988, with the rank of captain, in 1988 started his political career, as Rio de Janeiro Vereador (local councilman). After that, he won seven consecutive federal congress mandates.

Bolsonaro announced his pre-candidacy to the Presidency of Brazil in March of 2016 by the Christian Social Party, then in 2018 shifted to the Liberal Social Party (PSL) to run the elections 2018 (Folha de São Paulo, 2018). 
Bolsonaro's independent political position, and one of the most important critical success factors, comes from the fact that he did not make coalition with parties to dispute the second round elections, assuring the right for ministry indications, without being compromised with any political parties demands, usual in these circumstances. Candidates like João Doria, elected state governor in São Paulo state, along with the candidate Wilson Witzel, elected state governor in Rio de Janeiro. Both candidates supported publicly Jair Bolsonaro on social media and networks, without formal reciprocity from this candidate (TSE, 2018).

Evidence suggests that standard official Television propaganda is not significant anymore. Bolsonaro himself gave the proof of that. His party had only eight seconds to present the government programs. He barely could pronounce his name. In comparison, PT had almost five minutes of tv appearance, due to the parties' coalitions. Nevertheless, Bolsonaro beat PT.

The result of elections jumped to 52 PSL federal members of Congress elected (second large group elected), while PT decreased to 56 members of Congress elected, which means that Bolsonaro may find a continuous opposition from the defeated left-wing. Less of 50 percent of the congressmen succeeded in re-electing (TSE, 2018).

In 2019, the Brazilian Congress counts with 513 federal members of congress, from 30 different parties being represented. More than in 1998, with only 18 parties. Therefore, evidence suggests a power distribution, in opposition to a concentration, which means that Bolsonaro will have to make alliances to beat PT at the Congress. Nevertheless, his position is considered very strong, since he is supported by 52 coreligionist congressmen support him.

\section{Discussion :-}

The general elections 2018 has divided the country. As depicted in Figure 5, the northeastern region, traditionally Labor party's electoral corral, with the lowest human development Index (HDI), and one of the poorest Brazilian regions voted for the maintenance of the far-left government in Brazil, being beaten in all other regions (TSE, 2018).

In the recent Brazilian history, the violence has never victimized one candidate for the presidency. All the other candidates, including the acting president, Michel Temer, condemned the attack.

The elections in Brazil should not run in two rounds, but only one. The second round served initially been to consolidate power through alliances. However, it would not be suitable for political renewal. In this sense, Bolsonaro acted firmly and correctly, not doing any political alliances, especially with parties that try to selfperpetuate in power, like Partido do Movimento Democrático Brasileiro, PMDB, who lost 32 chairs in the Congress in 2018 (has 66 until the end of 2018), or PSDB, who lost 20 chairs (has 49 until the end of 2018), usually called Centrão (big center, our translation), together, very strong to represent their parties projects (TSE, 2018).

Levitsky and Ziblatt (2018), argued that American democracy, to survive, has to comply with two significant nonwritten norms: (a) Institutional Reserve, and (b) Mutual Tolerance, named as "the act of avoiding actions that, although respecting the letter of the Law, clearly disrespect its Spirit" (p.107).

As discussed by Dias \& Teles, 2018, "the left wing candidate Lula is a criminal that ridicules Brazilian Moral and Institutional Reserves. Both ways, democracy loses. Brazilian citizens are in between, dreaming with a Country with no corruption and respect for every citizen's rights." (p.13)

Additionally, the traditional form of conducting a political campaign was shaken by the advent of social networks, which have been intensely explored by all candidates, and fake news widespread to undermine their opponents.

According to Dias and Teles (2018), "the lesson we learned with this process is to double, triple check information, if necessary, questioning and searching relentlessly for reliable, true information." (p.14)

Finally, despite controversies, violence, fake news, international media opposition, and political maneuvers, the general elections 2018 occurred in the spirit of cooperation. According to Tribunal Superior Eleitoral (TSE), there were 480 occurrences throughout Brazil, none of them involving candidates, only voters. Out this total, 236 were electoral crimes that resulted in arrest to ensure order at polling places. (TSE, 2018). 
Future case revisitation is encouraged, to follow the newly democratic government in Brazil, its performance and impacts on several areas, such as Education, Economics, Health system, the end of corruption and violence, the country pacification, instead of the former widespread social classes division, among others, certainly represents a new hope for the future of the Brazilian citizens.

\section{References:-}

1. Brasil (1983). Lei de Segurança Nacional. $n^{\circ}$ 7.170, from December 14th, 1983.

2. Brasil (1988), Governo Federal. Constituição da República Federativa do Brasil.

3. Brasil (1997). Lei $\mathrm{N}^{\circ} 9.504$, de 30 de Setembro de 1997. Estabelece normas para as eleições. Retrieved from http://www.planalto.gov.br/ccivil_03/leis/L9504.htm, on September 16, 2018.

4. Brasil (2010). Lei complementar $n^{\circ} 135$, de 4 de junho de 2010. Altera a Lei Complementar no 64, de 18 de maio de 1990, que estabelece, de acordo com o § 9o do art. 14 da Constituição Federal, casos de inelegibilidade, prazos de cessação e determina outras providências, para incluir hipóteses de inelegibilidade que visam a proteger a probidade administrativa e a moralidade no exercício do mandato. Retrieved from

5. http://www.planalto.gov.br/ccivil_03/leis/lcp/Lcp135.htm, on October 30, 2018.

6. Câmara dos Deputados (2018). Conheça a história do voto no Brasil. Retrieved from

7. http://www2.camara.leg.br/camaranoticias/noticias/POLITICA/93439-CONHECA-A-HISTORIA-DO-VOTONO-BRASIL.html, on September 14, 2018.

8. Carvalho, José Murilo (2000). Cidadania no Brasil.o longo caminho. Rio de Janeiro: Civilização Brasilieira.

9. CPDOC (2018). E ele voltou... o Brasil no segundo governo Vargas. Retrieved from

10. https://cpdoc.fgv.br/producao/dossies/AEraVargas2/artigos/DoisGovernos/Redemocratizacao, on Sepetember 14, 2018.

11. Dias, Murillo; Teles, A.(2018) Vote in Brazil and general elections 2018: are the pillars of democracy in danger? In: Global Journal of Politics and Law Research. Vol.6, No.6, pp.1-15, October 2018

12. Dias, M. \& Davila Jr., E. (2018) Overcoming Succession Conflicts in a Limestone Family Business In Brazil. In: International Journal of Business and Management Review Vol.6, No.7, pp.58-73, August 2018,

13. Dias, Murillo \& Navarro, Rodrigo (2018). Is Netflix Dominating Brazil? In: International Journal of Business and Management Review. Vol.6, No.1, pp.19-32, January 2018

14. Dias, Murillo \& Navarro, Rodrigo (2017). O Fator Confiança em Relações Governamentais e sua importância para o futuro da atividade. In: Revista Brasileira de Relações Institucionais e Governamentais. 3a. Edição comemorativa, agosto de 2017, pp.38-41.

15. Dias, M.; Duzert, Y. (2017). Teaching Materials: Role Play Simulation on E-Business Negotiation. In:: European Journal of Training and Development Studies, Vol.4 No.3, pp.1-15, August 2017

16. Dias, M., (2016). São Francisco River Transposition Civil Work: Challenges to the Brazilian Economy. In: The International Journal of Business \& Management. Vol. 4, Issue 12, pp. 65-70.

17. Dias, Murillo; Alves, H.; Marcchesini, F.; Pezzella, M. São Francisco Valley: Vitiviniculture Activities in the Brazilian Unthinkable Semiarid Climate and its Challenges. In: International Journal of Business and Management Review Vol.4, No.10, pp.1-13, December 2016.

18. Dias, Murillo; Navarro, Rodrigo; Barros, J., Valle, A. (2016). Negotiating with the Brazilian Government: Five Short Cases. In: The International Journal Of Business \& Management, Vol. 4, Issue 11, pp. 181-189

19. Dias, Murillo et al. (2015). Brazilian Fashion Business Dudalina S/A: Case Revisited. In: International Journal of Business and Management Studies. ISSN: 2158-1479. Vol 04(01); p. 11-24.

20. Dias, Murillo et al. (2014). Dudalina S/A: Case Study on How to Overcome Succession Barriers on a Brazilian Family Business. In.Business and Management Review, vol 3, no. 12, special issue Brazil, ISSN 2047 - 0398 , pp. 217-229

21. Dias, Murillo et. al.(2014). Domestic Workers' Rights in Brazil: Improvement of Labor Regulation. In: Humanities and Social Sciences Review, vol.3(2), , ISSN 2165-6258, pp. 9-21

22. Dias, Murillo et. al.(2014). FIAT and Chrysler in Brazil: Anatomy of an Alliance. In: International Journal of Business and Management Studies, vol.3(1), ISSN 2158-1479, pp 1-13

23. Dias, Murillo, Navarro, R.; Valle, A. (2013). BMW and Brazilian Federal Government: Enhancing the Automotive Industry Regulatory Environment. In: International Journal of Arts and Sciences, 2013, volume 06, number 02, pp.551-567

24. Dias, Murillo (2012). Two Case Studies on how to Deal Effectively with Fixed plus Variable Costs Contracts. In: International Journal of Business and Management Studies2012, volume 01, number 03, ISSN 2158-147, pp. 505-515 
25. Dias et al. (2014).Dudalina S/A: Case Study on How to Overcome Succession Barriers on a Brazilian Family Business. In.Business and Management Review, vol 3, no. 12, special issue Brazil, ISSN 2047 - 0398, pp. $217-$ 229.

26. Dias, Murillo et al. (2015). Brazilian Fashion Business Dudalina S/A: Case Revisited. In: International Journal of Business and Management Studies. ISSN: 2158-1479. Vol 04(01); p. 11-24.

27. Eisenhardt, K. (1989). Agency theory: An assessment and review. In: Academy of Management Review, 14 (1): 57-74.

28. Folha de São Paulo (2018). Biografia de Bolsonaro. Retrieved from

29. https://www1.folha.uol.com.br/poder/2018/10/veja-a-biografia-de-jair-bolsonaro-presidente-eleito-dobrasil.shtml, on October 30, 2018.

30. Levistky, S. \& Ziblatt, D. (2018) Como as Democracias Morrem. Rio de Janeiro, Zahar.

31. Myers, M. D. (1997). Qualitative research in information systems. MIS Quarterly, 21(2), 241-242.

32. Nicolau, J. (2002). Historia do voto no Brasil. Rio de Janeiro: Editora Saraiva.

33. Saldaña, Johnny (2013).The Coding Manual for Qualitative Researchers. London: SAGE, $2^{\text {nd }}$ Edition.

34. The Guardian (2018).The fate of Lula da Silva is the very fate of Brazilian democracy Retrieved from https://www.theguardian.com/world/2018/apr/05/the-fate-of-lula-da-silva-is-the-very-fate-of-braziliandemocracy, on October 30, 2018

35. Tribunal Superior Eleitoral - TSE (2018) Estatísticas do Eleitorado. Retrieved from

36. http://www.tse.jus.br/eleitor/estatisticas-de-eleitorado/quantitativo-do-eleitorado, on Sepember 14, 2018.

37. Vote. (n.d.). Retrieved September 14, 2018, from https://www.merriam-webster.com/dictionary/voteWard, J.L. (1997). Growing the family business: Special challenges and best practices. In: Family Business Review, 10(4), 323-337.

38. Vote. Etymology online. Retrieved from https://www.etymonline.com/word/vote, on September 14, 2018.

39. Yin, R. (1988) Case Study Research: Design and Methods. Newbury Park, CA: Sage Publications. 